\title{
FEEDING OF THE Brycon cephalus, Triportheus elongatus AND Semaprochilodus insignis (OSTEICHTHYES, CHARACIFORMES) LARVAE IN SOLIMÕES/AMAZONAS RIVER AND FLOODPLAIN AREAS.
}

\author{
Rosseval Galdino LEITE', Carlos A.R.M. ARAUJO-LIMA
}

\begin{abstract}
Information on larval fish feeding is essential for understanding their trophic relations, including the management in conditions totally or partially controlled by humans. An experiment was designed to evaluate the larval diets of three commercially important species. Four varzea-lakes and the adjacent river were sampled with bongo and hand nets from January 1993 to November 1995. Larval diets were evaluated by length-classes and capture sites, and were tested by two factor ANOVA. The larvae were feeding in all habitats, except in the flooded forests. The three species had different diets, which varied with their length and lake. The rotifers were the main initial food item of the three species, replaced by fish larvae in Brycon cephalus, cladocerans in Triportheus elongatus and detritus in Semaprochilodus insignis. The increase of the ingestion limit, as the larvae grew, was higher than the increase in the consumed prey size for the three species.
\end{abstract}

Key-words: Amazon, Brazil, feeding, fish larvae, food size.

Alimentação das Larvas de Brycon cephalus, Triportheus elongatus e Semaprochilodus insignis (Osteichthyes, Characiformes), no Rio Solimões/Amazonas e suas Ảreas Inundáveis.

RESUMO - Informações sobre a alimentação das larvas de peixes são essenciais para entender suas relações tróficas, incluindo o manejo em condições controladas parcial ou totalmente pelo homem. Um experimento foi desenhado para avaliar a dieta das larvas de três espécies de importância comercial. Quatro lagos de várzea e o rio adjacente foram amostrados com rede de ictioplâncton de Janeiro de 1993 a Novembro de 1995. A dieta das larvas foi avaliada por classes de comprimento e locais de captura, e foram testadas por ANOVA com dois fatores. As larvas estavam alimentando-se em todos os habitats, exceto na floresta inundada. As três espécies apresentaram dietas diferentes, que variaram com o comprimento e com o lago. Os rotíferos foram o principal item alimentar para as três espécies no início da alimentação exógena, e depois substituídos por por larvas de peixes em Brycon cephalus, cladóceros em Triportheus elongatus e detritos em Semaprochilodus insignis. O aumento do limite de ingestão das larvas com o crescimento, foi maior que o aumento no tamanho da presa consumida para as três espécies.

Palavras-chaves: Amazônia, Brasil, alimentação, larvas de peixes, tamanho de alimento.

\section{Introduction}

\section{Matrinxã (Brycon cephalus,} Günther, 1866), sardinha (Triportheus elongatus, Günther, 1864) and jaraqui (Semaprochilodus insignis, Schomburgki in: Jardine, 1841), are commercially important fishes of Amazonas State. They belong to the groups of Amazonian fish that reproduce in the river channels. Their larvae are carried to flooded areas (Petry, 1989; Oliveira \& Araujo-Lima, 1998), which are their nursery grounds (Leite, 2000).

Fish larval food availability is linked to water level oscillations. These allow for a nutrient reposition between river and flooded areas, causing development of the local fauna, primarily in the early rising water period. Some fish larvae are carried from

Instituto Nacional de Pesquisas da Amazônia, C. P. 478, Manaus - 69011-970, AM, Brasil. leitegr@inpa.gov.br. 
the main river channel to near aquatic plants in the floodplain (Leite, 2000; Leite \& Araujo-Lima, 2000). Micro invertebrates, which may be eaten by fish larvae, also occur near vegetation (Junk, 1973).

Neotropical fish larvae tend to prey upon immature insects in addition to small crustaceans (MachadoAllison, 1987; Araujo-Lima \& Goulding, 1997; Mérigoux \& Ponton, 1998). However, morphological differences between fish larvae, primarily mouth size, do not allow predation on the same kind of prey.

Mouth size appears to be the limiting factor in juvenile fish feeding on natural and pelleted diets (Hyatt, 1979). According to Dabrowski \& Bardega (1984), a linear relationship was found between mouth size and the total length of fish, from the initial exogenous feeding stage, up to 20 $30 \mathrm{~mm}$. Ito \& Suzuki (1977), measured the mouth width of loach and presented evidence, from gut analysis, that the size of the first food was 0.20.4 times the mouth size.

In all, different relationships could be expected on species level and between species with growth. Based on these differences, ontogenetic changes could be expected too.

Ontogenetic changes in the larval diet of the three Solimões/ Amazonas river fish species, including larvae from the first exogenous feeding to the last larval stage, are described in this paper. Samples were collected in four independent varzealakes, including main habitats in the river and floodplain, in order to under- stand spatial variation along the basin. Gerking's (1994) hypothesis, on the tendency of fish larvae to consume cladocerans and rotifers and ingest intermediary prey according to the size of their mouth, was also tested.

\section{Materials and Methods}

The sample area in the Solimões/ Amazonas river, was located between $66^{\circ}$ and $60^{\circ} \mathrm{W}$ longitude and $2^{\circ}$ and $4^{\circ}$ latitude, equivalent to a section of 650 $\mathrm{Km}$. Four lakes were sampled in this section: Janauacá, Rei, Camaleão and Jacare as well as the parts of the river linked to the lakes. The first three lakes are located near Manaus, and the fourth, in the eastern limit of the study area (Fig.1). The water level in lakes and river varies seasonally, low in Oct.-Nov. and high in Jun.-Jul. (Fig. 2).

The lakes near Manaus, were sampled from December 1993 to December 1995. The captures were more frequent between September and April, on account of greater larvae availability. Jacaré lake, was visited only once in November 1995. Seven mesohabitats were sampled: 1) middle lake, a lentic environment, located in an intermediary line between lake margins; 2) lake channel, a lotic environment, linking river and lakes; 3) river channel, a lotic environment, located in the middle of main river channel; 4) river margin, a lotic environment, situated up to $3 \mathrm{~m}$ from the river margin; 5) macrophytes (primarily flooded grasses), a lentic environment, with floating or rooted to the bottom vegetation; 6) near macrophytes, a region located nearly $1 \mathrm{~m}$ from the 
flooded macrophytes on the edge of the lake; 7) Flooded forest, is a lentic environment, located among flooded forest trees, in várzea soil.

Each habitat (except for aquatic plants), was sampled with three replicates by lake and capture date. Larvae were sampled with a conic-cylindrical $2 \mathrm{~m}$ long bongo net with a $50 \mathrm{~cm}$ aperture diameter. Towing was performed at $1 \mathrm{~m} \cdot \mathrm{s}^{-1}$ velocity for five minutes.

Hand net with $30 \times 20 \mathrm{~cm}$ mouth area was used for sampling within the aquatic plants. Each sampling with a hand net sum up 10 throws. Following each hand net sampling, the captured larvae were removed and preserved in a $10 \%$ formalin solution. Four samples (replicates) were taken from aquatic plant areas, for lake and collection date.

The bong net was put on the side of the boat. The larvae removed from the collecting cup were fixed in a $10 \%$ formalin solution. The bongo net was washed for any remaining traces of the former catch. It was not possible to use the bongo net in the flooded forest.

\section{Methods}

Samples were sorted on a stereomicroscope for separating larvae by species. Larvae were identified according to Araujo-Lima \& Donald

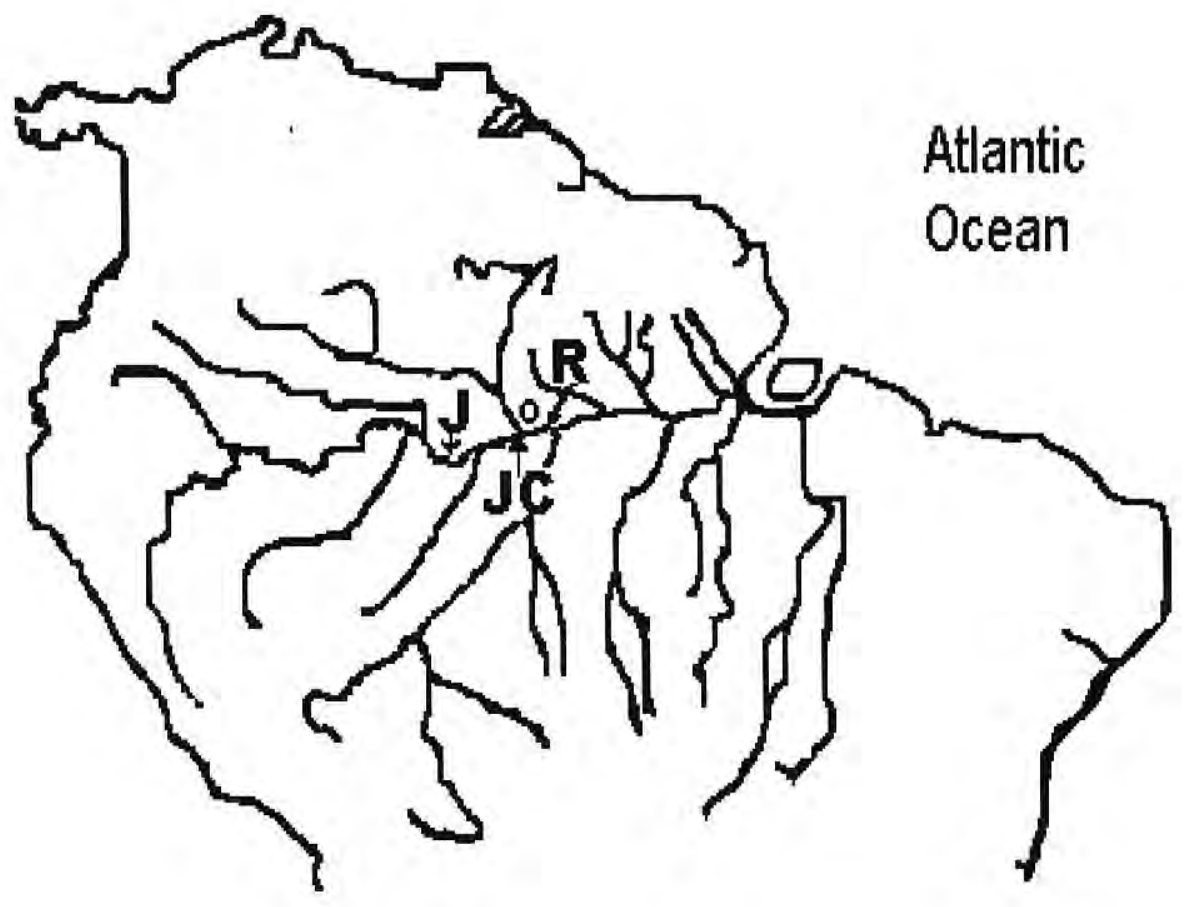

Figure 1. Sample sites in Solimões/Amazonas river. J - Jacaré lake, JC - Janauacá and Camaleão lakes, R - Rei lake. The circle indicates the city of Manaus, Brazil. 


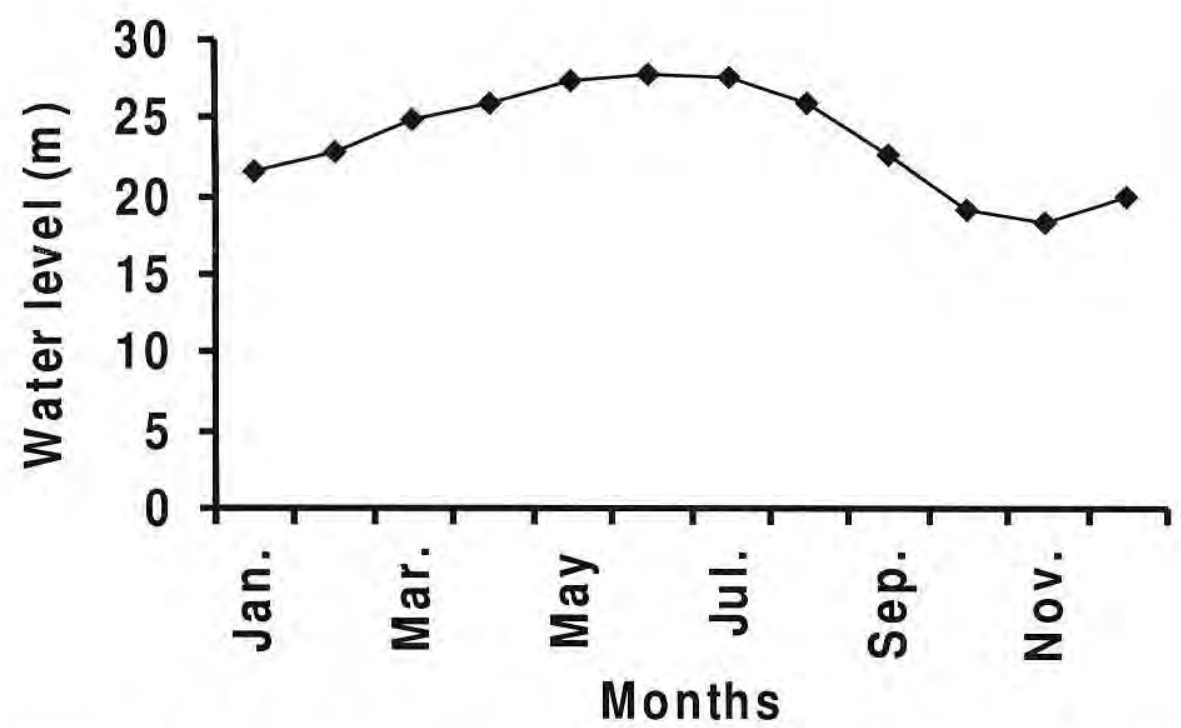

Figure 2. Solimões/Amazonas river monthly mean water levels from January 1988 to December 1998 .

(1988) and Araujo-Lima et al. (1993), using pigment criterion and the total miomers count. When in doubt, larvae were examined again for identification confirmation. When identification was not possible, larvae were discarded. Larvae were kept in a $10 \%$ formalin solution.

Larval length and mouth diameter $(\mathrm{mm})$ were measured. They were separated by length classes according to species. Larvae without stomach, classified in the initial feeding exogenous phase; whereas those with vestigial stomachs, were in the intermediary phase; and those with piloric cecum present, at the final feeding phase. Larval phase was according to Araujo-Lima (1994). Mouth diameter was obtained by using expression $1.41 \cdot d$, where $d$ is the distance between the anterior and posterior premaxillary and maxillary part of the larvae, according to Leite \& AraujoLima (2000). The relative number larval of each species with empty stomachs per habitat was evaluated. Larval stomach content, was analyzed in randomized individuals, representing all lakes, habitats and length classes.

Food items were counted, identified and grouped in the following categories: insect larvae, fish larvae, planktonic and benthic cladocerans, ciclopoid, calanoid and harpactcoid copepods, copepod nauplii, ostracods, shrimp zoea, rotifers, nematoids, protozoan, algae, detritus (Koste, 1978; Needhan \& Needhan, 1978; SuarezMera, 1980; McCafferty \& Provonsha, 1983; Korinek, 1984; Paggi, 1995). Food amounting to less than $5 \%$, per larvae, were grouped as "other foods". The relative food categories contribution to the diet of larvae, was measured in relation to total dry weight 
(mg) in alimentary tract content. Cladoceran, copepod and rotifer weights were estimated by using length $X$ weight equations (Dumont et al., 1975). The chironomid contribution was obtained through their volumes $\left(\mathrm{mm}^{3}\right)$, where the dry weight $(\mu \mathrm{g})=21+3 *$ volume $(\mathrm{r}=$ 0,$98 ; \mathrm{N}=6$ ). The chironomids volume was adjusted by considering their body cylinder- like in form. Their weight was obtained after drying, up to constant weight, of chironomids from equal volume classes at $60^{\circ} \mathrm{C}$. This formula was used for other insect larvae. Fish larval dry weight was obtained with equations for two categories: 1 - the relatively long headed and short bodied larvae, where weight $(\mathrm{mg})=0,0059 * \mathrm{LS}^{2.061}(\mathrm{~N}=17$; $r=0,96)$ and; 2 - relatively short headed and long bodied larvae where weight $(\mathrm{mg})=0,0081^{*} \mathrm{LS}^{2.000}(\mathrm{~N}=14 ; \mathrm{r}=$ $0,98)$, where LS is the larvae standard length $(\mathrm{mm})$. The other food items dry weight was also obtained through stove drying, except for protozoa, which were compared to rotifer eggs, with identical length and form. It was not possible to obtain algae dry weight, by weighing them, mainly because it was rare to find any of them in the stomachs of the fish larvae.

Each alimentary category variation in diet, was analyzed by length class $(2 \mathrm{~mm})$ and catch site, being each observation composed by one larva, and tested with ANOVA with two factors: one fixed (length weight) and one variable (lake), but only including samples from the habitats where larvae were feeding. The data, in percentage, were changed to arc-sin prior to ANOVA. Preliminary analysis showed that, in a same species, the diet types were always more influenced by length and catch site. These analyses only allowed to identify the lakes and length effects. Each food contribution by length, was not independent, because of this, the quantitative diet composition was not feasible, yet, the food contribution, was described in a semi-quantitative form.

The diameter/width of the particles ingested by fish larvae, was measured in a stereomicroscope. The theoretical ingestion limit (TIL), was correspondent to $50 \%$ of the mouth diameter in each species (Shirota, 1970). All measurements were relative to larval length, and the data were analyzed with linear regression, by using the least square means.

\section{Results Feeding sites}

Brycon cephalus and T. elongatus larvae were feeding in the river channel, river margin, lake channel and flooded plants. Semaprochilodus insignis larvae only fed at river margin and flooded plants (Tab. 1). Brycon cephalus and $T$. elongatus larvae presented feeding incidence superior to $50 \%$ in most mesohabitats where they were captured, while this was observed in $S$. insignis only in the aquatic plants (Tab. 1).

Small larvae of the three species occur in the river channel (channel and margin) and the large larvae in the aquatic plants, except for $B$. cephalus, where the large larvae also lived in the river channel. Larvae of the three species were not captured in the flooded forest. 
Table 1 - Larval catch data $(\mathrm{N})$, food ratios (\%) and standard length range (SL), by species and habitat, in Solimoes/Amazonas river and floodplain, from Dec. 93 to Nov. 95. RC - river channel, RM - river margin, LC - lake channel, LM - lake middle, NP - near macrophyte and $\mathbf{B M}$ - between macrophyte.

\begin{tabular}{lccccccc}
\hline SPECIES & Meso-habitat & RC & RM & LC & LM & NM & BM \\
\hline Brycon cephalus & $\mathrm{N}$ & 500 & 1033 & 13 & 0 & 0 & 2131 \\
& $\%$ & 25 & 82.2 & 100 & - & - & 100 \\
& $\mathrm{SL}$ & $6.3-15$ & $6.3-15$ & $6.3-15$ & - & - & $9.2-17$ \\
Triportheus elongatus & $\mathrm{N}$ & 403 & 2943 & 153 & 116 & 0 & 4609 \\
& $\%$ & 23.03 & 75 & 35 & 100 & - & 100 \\
Semaprochilodus insignis & $\mathrm{SL}$ & $3.9-4.5$ & $3.9-4.5$ & $7.5-10$ & $6-9$ & - & $7.1-18$ \\
& $\mathrm{~N}$ & 1524 & 11012 & 60 & 0 & 501 & 929 \\
& $\%$ & 0 & 40 & 0 & - & 0 & 83.33 \\
& $\mathrm{SL}$ & $5.4-7$ & $5.4-6$ & - & - & - & $6-17$ \\
\hline
\end{tabular}

\section{Diet}

The food eaten by B. cephalus larvae, depends on their length and lakes with aquatic plants (Fig. 3; Tab. 2). This species was also feeding in the river channel, primarily on other fish larvae. In Camaleão and Rei lakes, where larvae smaller then $7 \mathrm{~mm}$ occurred, rotifers were their main food, representing more than $50 \%$ of their diet (Tab. 2). Other fish larvae were the main food for larvae larger than 9 $\mathrm{mm}$, contributing more than $80 \%$. Planktonic cladocerans, whose variation depended on length and lakes, contributed more in the $9 \mathrm{~mm}$ larvae (Fig. 3).

Smaller $6 \mathrm{~mm}$ long T. elongatus larvae, were only captured in Jacaré and Rei lakes. In the river margin, in front of these two lakes, the diet of the $4 \mathrm{~mm}$ larvae was composed of rotifers. In Rei lake, planktonic cladocerans and "other food" were more important for $6 \mathrm{~mm}$ long larvae $(p<0,05)$. In the river margin across from Jacare lake, the $6 \mathrm{~mm}$ long larvae diet was exclusively of rotifers, being this food item also important in the Camaleão and Rei lakes (Fig. 4, Tab. 2). Their main feeding site, aquatic plants, the planktonic cladocerans contributed on average of $44 \%$ of the diet of these larvae in all lakes. Benthic cladocerans were statistically eaten more in Rei and Jacare lakes and the chironomids were only important (in average $>10 \%$ of the diet), in Janauacá lake (Fig. 4). The other food items had few representatives in the diet of this species, with a contribution in the diet of below $10 \%$.

The proportion of rotifers, detritus and planktonic cladocerans in $S$. insignis larvae diet, also presented an interaction between length and site in the river margin and aquatic plant environments (Fig. 5; Tab. 2). Rotifers represented more than $60 \%$ of the food content, in 6 and $8 \mathrm{~mm} \quad$ long larvae.

In 10,12 and $14 \mathrm{~mm}$ long larvae, detritus and sediment exceeded $87 \%$ 
of the food content (Fig. 5), and content of organic material aggregated to detritus, represented $30.3 \pm 4.6 \%$ (N $=5$ ). There was variation of plankton cladocerans in the diet contribution between lakes (Fig. 5). Cyclopoid copepods were not important in $S$. insignis larvae diet. In general, the species changed their initial diet as they grew, replacing rotifers by other food categories (Tab. 3).

Theoretical Ingestion Limit
(TIL) and prey length

Width and diameter of the prey, and theoretical ingestion limit, were increased with larvae length, but in different rates. The increase of the ingestion limit as the larvae grew, was higher than the increase on the consumed prey size for the three species larvae (Figs. $6-8$ ). Their prey diameter rarely exceeded this limit, except on the shorter $T$. elongatus larvae.
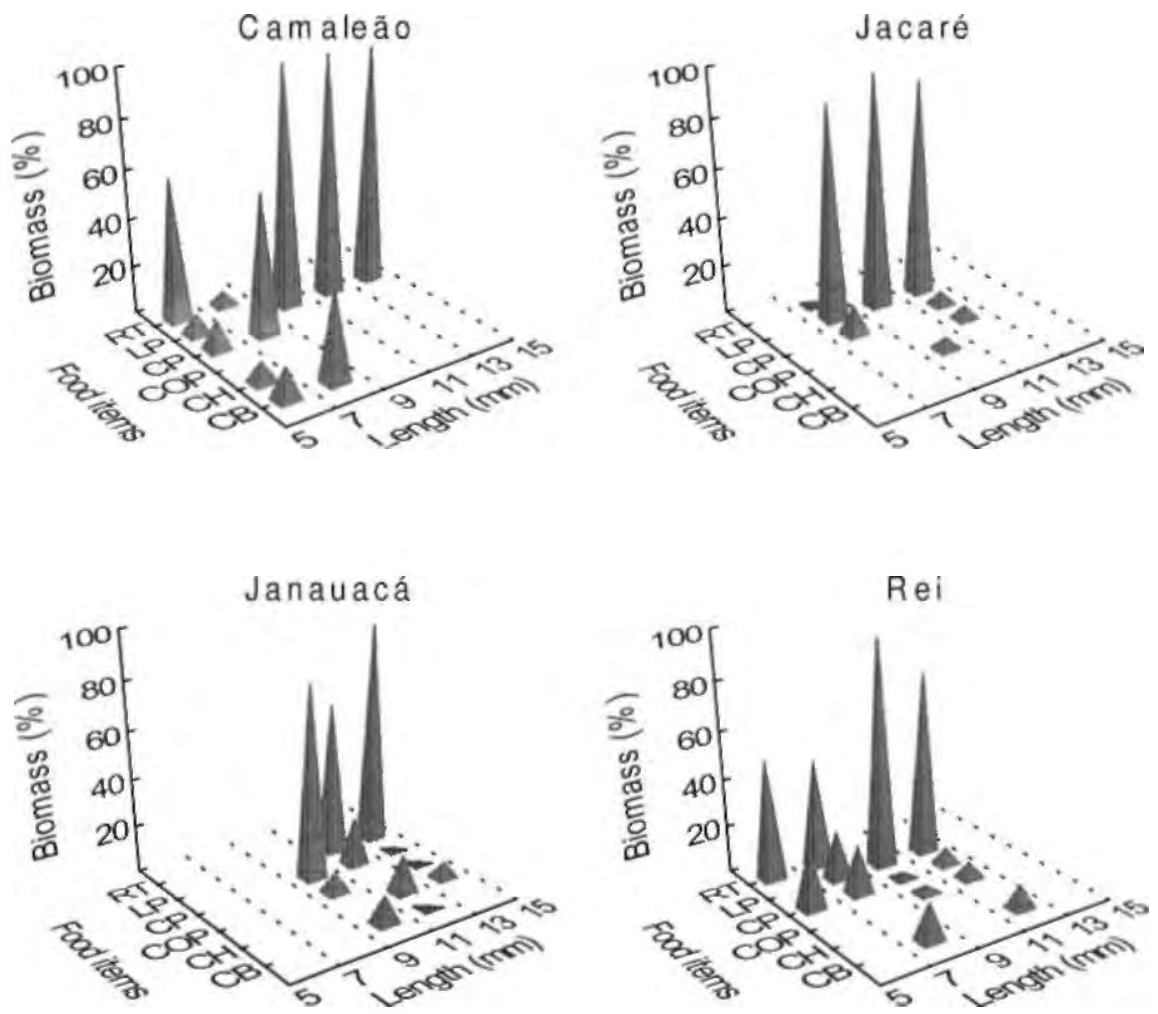

Figure 3. Food itcm proportions (\%) relative to the Standard length (mm) of Brycon cephalus larvac in four lakes of Solimões/Amazonas river. $\mathbf{C b}$ - Benthic cladocerans, $\mathbf{C h}$ - Chironomids larvae, $\mathbf{C p}$ - Planktonic cladocerans, Lp - Fish larvae, Rt - Rotifers and $\mathbf{O u}$ - Other food items. 
Table 2. Analyses of Variation (mixed model) of the food contribution in fish larvae of the Solimões/Amazonas river and floodplain, by length and lakes, between Dec. 93 and Nov. 1995.

\begin{tabular}{|c|c|c|c|c|}
\hline \multicolumn{5}{|c|}{ Brycon cephalus } \\
\hline & D. F. & M. S. & $\mathrm{F}$ & $\mathrm{P}$ \\
\hline \multicolumn{5}{|l|}{ Rotifers } \\
\hline Lakes & 3 & 936.9 & 8.904 & $<0.001$ \\
\hline S.L. & 3 & 3554.4 & 3.697 & 0.055 \\
\hline Lakes $\times$ S.L. & 9 & 962.0 & 9.142 & $<0.001$ \\
\hline Error & 136 & & & \\
\hline \multicolumn{5}{|c|}{ Benthic cladocerans } \\
\hline Lakes & 3 & 234.6 & 3.112 & 0.029 \\
\hline S.L. & 3 & 375.8 & 1.190 & 0.367 \\
\hline Lakes $\times$ S.L. & 9 & 315.9 & 4.19 & $<0.001$ \\
\hline Error & 136 & 75.4 & & \\
\hline \multicolumn{5}{|c|}{ Plankton cladocerans } \\
\hline Lakes & 3 & 2248.4 & 7.897 & $<0.001$ \\
\hline S.L. & 3 & 1991.4 & 1.612 & 0.254 \\
\hline Lakes $\times$ S.L. & 9 & 1235.0 & 4.338 & $<0.001$ \\
\hline Error & 136 & 284.7 & & \\
\hline \multicolumn{5}{|l|}{ Chironomids } \\
\hline Lakes & 3 & 114.6 & 1.193 & 0.315 \\
\hline S.L. & 3 & 61.6 & 0.789 & 0.530 \\
\hline Lakes $\times$ S.L. & 9 & 78.1 & 0.813 & 0.605 \\
\hline Error & 136 & 96.1 & & \\
\hline \multicolumn{5}{|l|}{ Fish larvae } \\
\hline Lakes & 3 & 6537.2 & 10.52 & $<0.001$ \\
\hline S.L. & 3 & 8622.8 & 1.796 & 0.218 \\
\hline Lakes $\times$ S.L. & 9 & 4801.2 & 7.726 & $<0.001$ \\
\hline Error & 136 & 621.4 & & \\
\hline \multicolumn{5}{|l|}{ Other foods } \\
\hline Lakes & 3 & 1117.4 & 7.146 & $<0.001$ \\
\hline S.L. & 3 & 1834.9 & 2.112 & 0.169 \\
\hline Lakes $\times$ S.L. & 9 & 869.0 & 5.558 & $<0.001$ \\
\hline Error & 136 & 156.4 & & \\
\hline
\end{tabular}

Triportheus elongatus

\begin{tabular}{lcccc}
\hline Rotifers & & & & \\
Lakes & 3 & 1943.8 & 1.69 & 0.177 \\
S.L. & 3 & 280.9 & 0.101 & 0.865 \\
Lakes $\times$ S.L. & 9 & 2782.3 & 2.419 & 0.018 \\
Error & 72 & 1150.4 & & \\
\hline
\end{tabular}


Table 2. Continuation

\begin{tabular}{|c|c|c|c|c|}
\hline $\begin{array}{l}\text { Benthic cladocerans } \\
\text { Lakes } \\
\text { S.L. } \\
\text { Lakes } \times \text { S.L. } \\
\text { Error }\end{array}$ & $\begin{array}{c}3 \\
3 \\
9 \\
72\end{array}$ & $\begin{array}{c}1437.8 \\
356.70 \\
139.6 \\
289.5\end{array}$ & $\begin{array}{l}4.967 \\
2.555 \\
0.482\end{array}$ & $\begin{array}{l}0.003 \\
0.120 \\
0.882\end{array}$ \\
\hline $\begin{array}{l}\text { Plankton cladocerans } \\
\text { Lakes } \\
\text { S.L. } \\
\text { Lakes x S.L. } \\
\text { Error }\end{array}$ & $\begin{array}{c}3 \\
3 \\
9 \\
72\end{array}$ & $\begin{array}{c}566.2 \\
869.2 \\
1563.3 \\
1208.4\end{array}$ & $\begin{array}{l}0.469 \\
0.556 \\
1.294\end{array}$ & $\begin{array}{l}0.705 \\
0.657 \\
0.255\end{array}$ \\
\hline $\begin{array}{l}\text { Cyclopoid copepods } \\
\text { Lakes } \\
\text { S.L. } \\
\text { Lakes } \times \text { S.L. } \\
\text { Error }\end{array}$ & $\begin{array}{c}3 \\
3 \\
9 \\
72\end{array}$ & $\begin{array}{c}231.91 \\
153.7 \\
95.1 \\
161.43\end{array}$ & $\begin{array}{l}1.437 \\
1.616 \\
0.589\end{array}$ & $\begin{array}{l}0.239 \\
0.253 \\
0.802\end{array}$ \\
\hline $\begin{array}{l}\text { Chironomids } \\
\text { Lakes } \\
\text { S.L. } \\
\text { Lakes x S.L. } \\
\text { Error }\end{array}$ & $\begin{array}{c}3 \\
3 \\
9 \\
72\end{array}$ & $\begin{array}{c}1203.69 \\
253.4 \\
301.4 \\
339.0\end{array}$ & $\begin{array}{l}3.551 \\
0.841 \\
0.889\end{array}$ & $\begin{array}{l}0.019 \\
0.505 \\
0.539\end{array}$ \\
\hline $\begin{array}{l}\text { Other foods } \\
\text { Lakes } \\
\text { S.L. } \\
\text { Lakes } \times \text { S.L. } \\
\text { Error }\end{array}$ & $\begin{array}{c}3 \\
3 \\
9 \\
72\end{array}$ & $\begin{array}{c}260.83 \\
224.1 \\
168.5 \\
221.7\end{array}$ & $\begin{array}{l}1.177 \\
1.011 \\
0.76\end{array}$ & $\begin{array}{l}0.325 \\
0.393 \\
0.653\end{array}$ \\
\hline
\end{tabular}

\section{Semaprochilodus insignis}

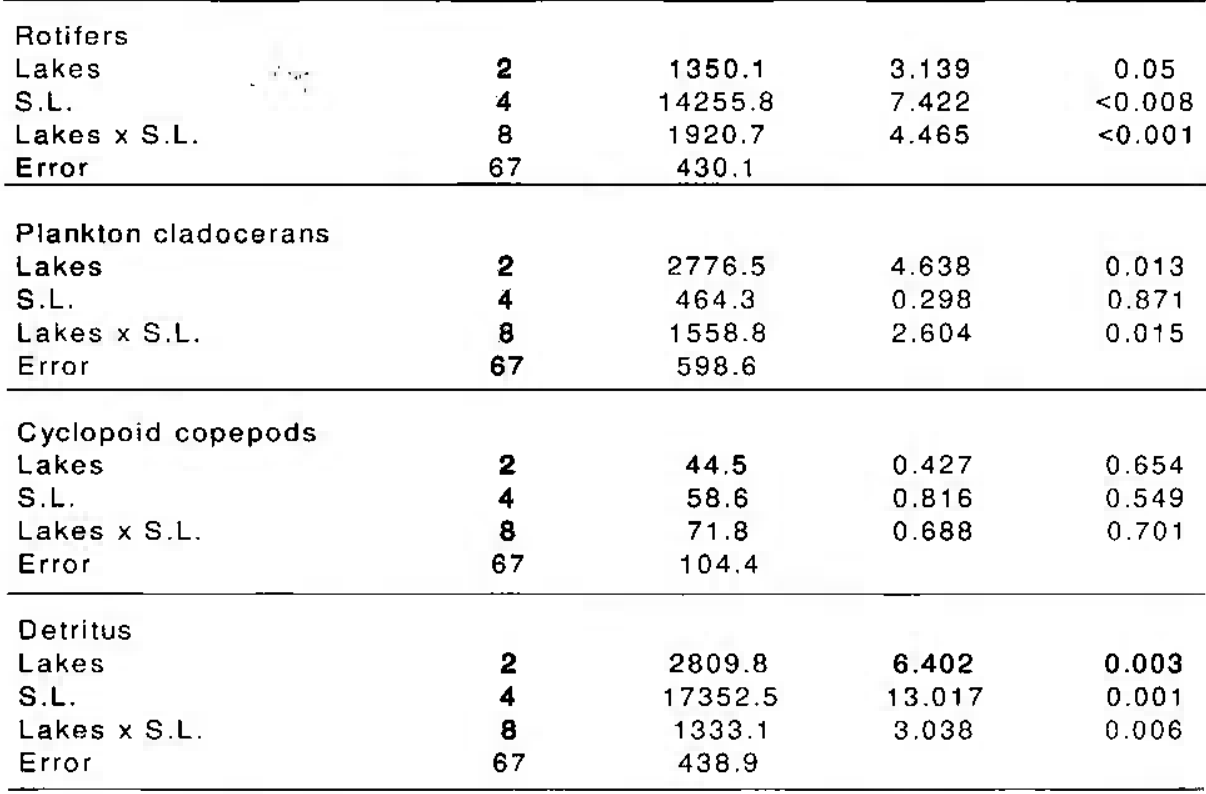



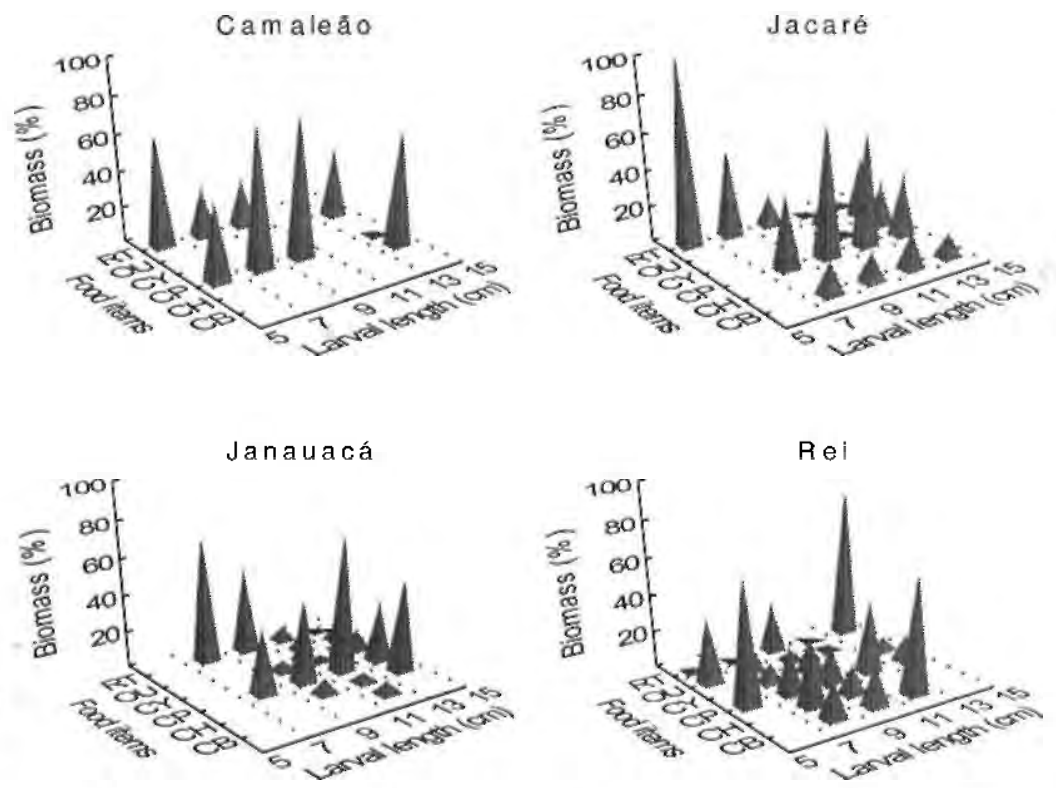

Figure 4. Food items proportions $(\%)$ relative to the Standard length $(\mathrm{mm})$ of Triportheus elongatus larvae in four lakes of Solimões/Amazonas river. $\mathbf{C b}-$ Benthic cladocerans, $\mathbf{C h}$ Chironomids larvae, $\mathbf{C p}$ - Planktonic cladocerans, $\mathbf{C y}$ - Cyclopoid copepods, $\mathbf{R t}$ - Rotifers and Ou - Other food items.
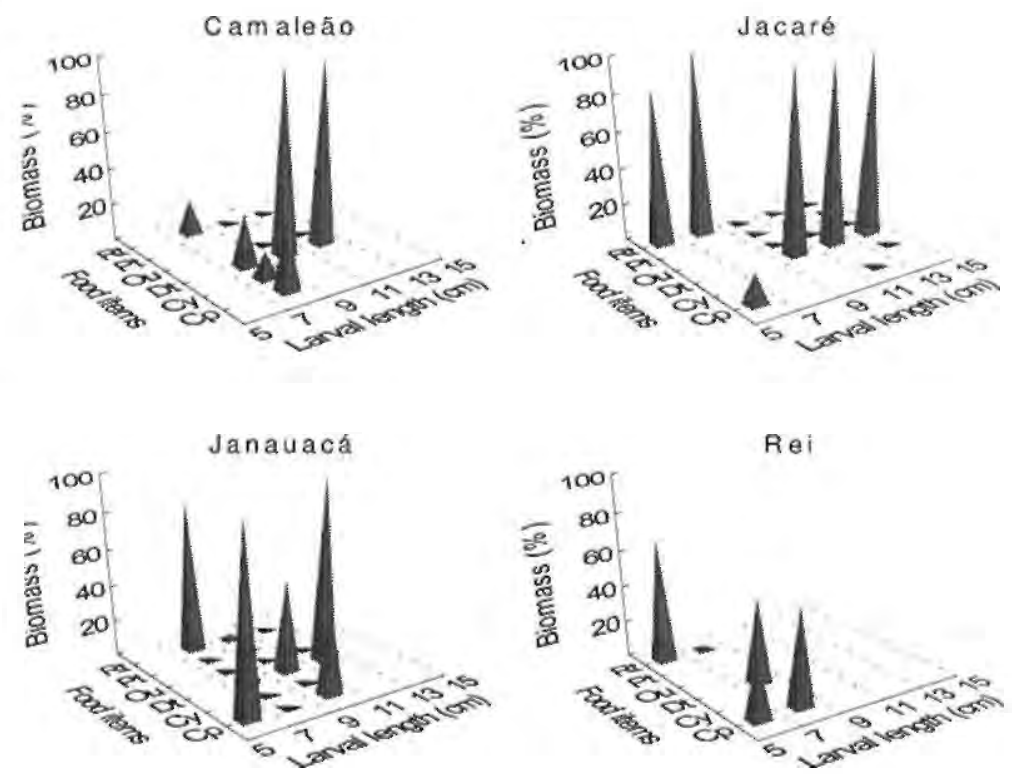

Figure 5. Food items proportions (\%) relative to the Standard length $(\mathrm{mm})$ of Semaprochilodus insignis larvae in four lakes of Solimões/Amazonas river. $\mathbf{C p}$ - Planktonic cladocerans, $\mathbf{C y}$ Ciclopoid copepods, Dt - Detritus and sand and Rt - Rotifers. 
Table 3. Fish larvae diet summary, with mean contribution (\%) by feeding phase, in Solimões/ Amazonas river and floodplain areas.

\begin{tabular}{|c|c|c|c|c|}
\hline \multirow[t]{2}{*}{ Feeding phase } & \multirow[t]{2}{*}{ Food items } & \multicolumn{3}{|c|}{ Species } \\
\hline & & B. cephalus & S. insignis & T. elongatus \\
\hline \multirow{9}{*}{ Initial } & Calanoid copepods & 0 & 0 & 0 \\
\hline & Benthic cladocerans & 16 & 0 & 0 \\
\hline & Chironomid larvae & 6 & 0 & 0 \\
\hline & Plankton cladocerans & 15 & 30 & 27 \\
\hline & Cyclopoid copepods & 0 & 0 & 0 \\
\hline & Insect larvae & 0 & 0 & 0 \\
\hline & Fish larvae & 6 & 0 & 0 \\
\hline & Others & 0 & 0 & 4 \\
\hline & Rotifers & 56 & 70 & 69 \\
\hline \multirow{9}{*}{ Intermediary } & Calanoid copepods & 0 & 0 & 0 \\
\hline & Benthic cladocerans & 15 & 0 & 7 \\
\hline & Chironomid larvae & 0 & 0 & 5 \\
\hline & Plankton cladocerans & 11 & 17 & 48 \\
\hline & Cyclopoid copepods & 0 & 3 & 4 \\
\hline & Insect larvae & 0 & 0 & 0 \\
\hline & Fish larvae & 69 & 0 & 0 \\
\hline & Others & 0 & $51\left(^{*}\right)$ & 1 \\
\hline & Rotifers & 5 & 29 & 35 \\
\hline \multirow{9}{*}{ Final } & Calanoid copepods & 0 & 0 & 0 \\
\hline & Benthic cladocerans & 3 & 0 & 10 \\
\hline & Chironomid larvae & 2 & 0 & 16 \\
\hline & Plankton cladocerans & 3 & 1 & 46 \\
\hline & Cyclopoid copepods & 0 & 1 & 7 \\
\hline & Insect larvae & 0 & 0 & 4 \\
\hline & Fish larvae & 80 & 0 & 0 \\
\hline & Others & 10 & $97\left({ }^{*}\right)$ & 10 \\
\hline & Rotifers & 2 & 1 & 7 \\
\hline
\end{tabular}

(*) represent detritus contribution

\section{Discussion}

Feeding sites

Larvae from the three species presented feeding activity in river channel and flooded areas in the beginning of the exogenous feeding. Aquatic plants were their main feed- ing site. Eight out of ten larvae from these species, were feeding in flooded plants when captured. This behavior might to be a reflex of the better locomotion conditions and prey availability, considering that an exuberant invertebrate fauna grows in the areas near the plants (Junk, 1973), perhaps 


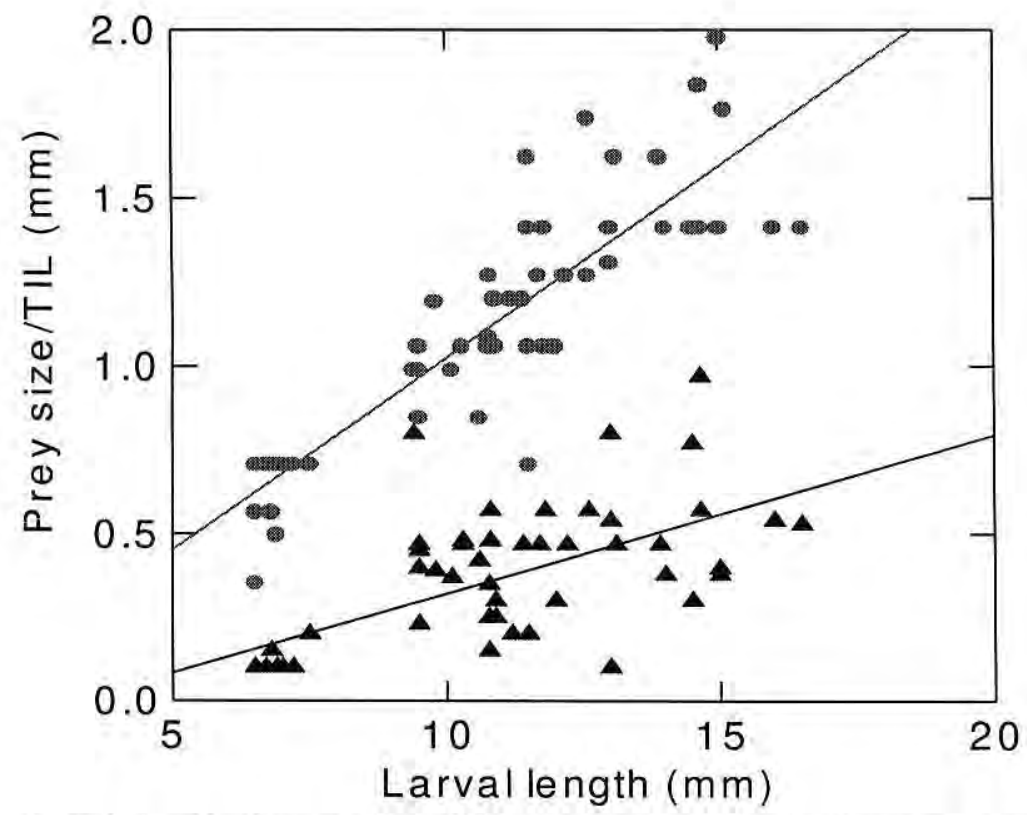

Figure 6. Relationships between size of the prey, represented by its diameter (triangle) and Theoretical Ingestion Limit (circle), according to the larval size, of Brycon cephalus, adjusted by linear regressions.

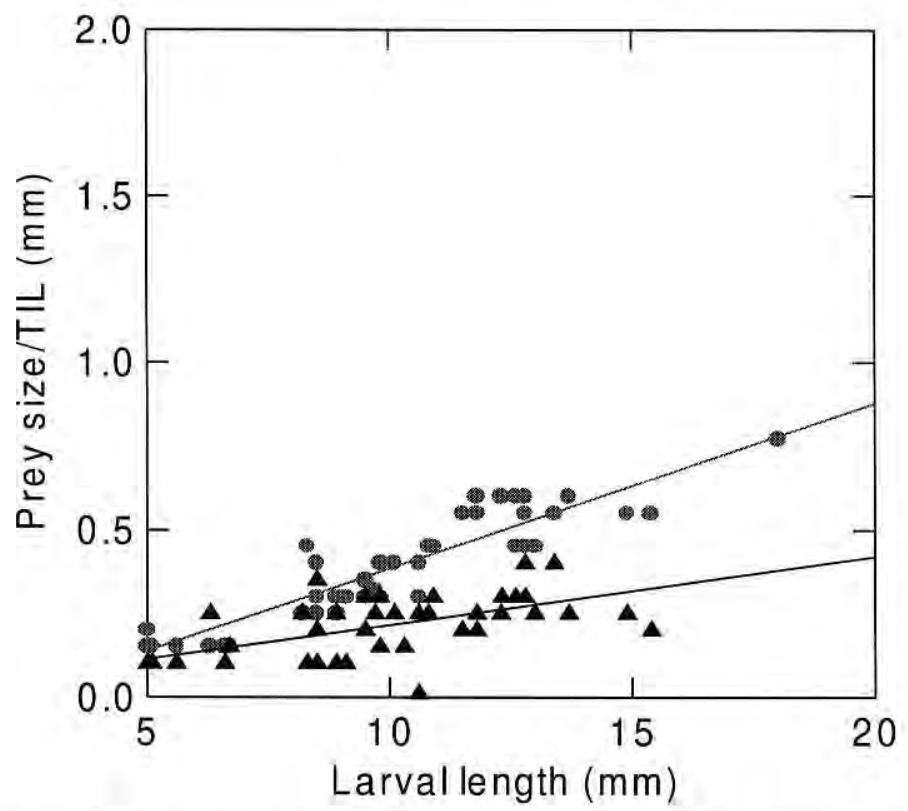

Figure 7. Relationships between size of the prey represented by its diameter (triangle) and Theoretical Ingestion Limit (circle), according to the larval length of Triportheus elongatus, adjusted by linear regressions. 


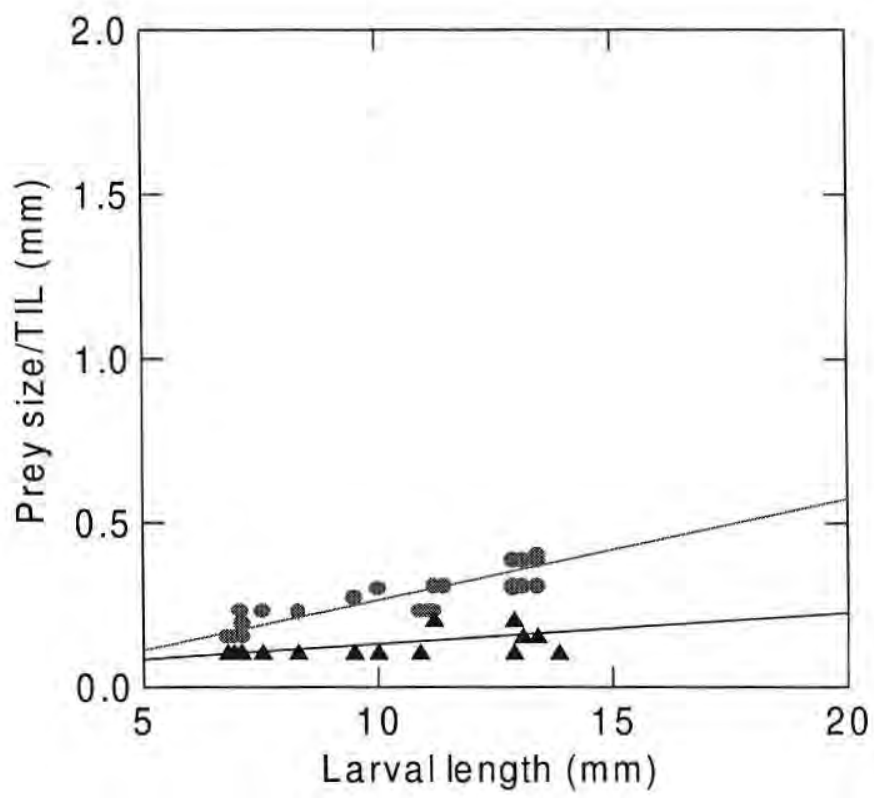

Figure 8. Relationships between size of the represented by its diameter (triangle) and Theoretical Ingestion Limit (circle) according to the larval length of Semaprochilodus insignis larvae, adjusted by linear regressions.

due to the low interference by water turbulence.

Prey availability is not solely responsible for the greater food incidence observed in flooded plants. Zooplankton abundance in lake open areas, may reach 500 ind. $\mathrm{I}^{-1}$ (Carvalho, 1981; Fisher et al;; 1983; Robertson \& Hardy, 1984), being equal or superior to that recorded for aquatic plants by Junk (1973), which indicates 100.000 ind. $\mathrm{m}^{-2}$ mainly in Paspalum repens concentrations.

Visibility might be factor that influences the activities of capturing prey. Fish larvae are predators and depend on vision for identifying and attacking their prey. Light incidence in water column, which serves to modulate the visibility, would be an important factor on their predation effi- ciency. In the aquatic plants and lake, the penetration of light in water column, exceeded $100 \mathrm{~cm}$ (Hardy, 1992; Furch \& Junk, 1997). In short, the alimentary incidence on fish larvae from the Solimões/Amazonas river, is not related to prey visibility.

The absence of $B$. cephalus and $S$. insignis in the middle of the lake, does not allow for comparing their feeding incidence to $T$. elongatus larvae in those habitats. It is possible that T. elongatus shift to the middle of the lake, due to the presence of cladocerans, which are their principal prey.

The major difference between feeding incidence of the larvae was shown by B. cephalus. All larvae from this species were feeding in the lake channel, when captured. T. elongatus and $S$. insignis, present feeding inci- 
dence lower than $40 \%$ in that habitat. $B$. cephalus and $T$. elongatus were feeding in river channel, reaching a feeding incidence of around $25 \%$, while $S$. insignis was not feeding in river channel. In all, the initial feeding by these caraciforms larvae species is not exclusively due to prey availability and visibility, but probably includes others factors.

\section{Food contribution}

Relative food contribution by length, did depend on the lakes for three species. Because of this, the diet was analyzed by lake, and the generalities about their diets, are relatively limited. Variations between lakes could be related to the hydrological cycle, according to Bayley (1988), and/or limnetic characteristics of the lakes.

Diet changes in tropical fishes, are normally due to the seasonal food available (Almeida, 1980; Goulding, 1980; Carvalho, 1981; Angermeier, 1982; Santos, 1982; Boujard et al., 1990). Cyclical environmental factors of short and medium duration, like distribution of small crustaceans on water column during the day (Fisher et al, 1983), or hydrological cycles (Rabelo, 1999), may influence prey availability. However, it is possible fish larvae show changes due to their diet plasticity or active prey selection (Mérigoux \& Ponton, 1998), often as a consequence of occasional food offerings (Goulding, 1980, LoweMcConnel, 1987).

Information is scarce about neotropical fish larvae diets. The most complete data are based on the diet of 66 species (Merigoux \& Ponton, 1988). They showed most larvae, regardless of their taxonomic group, were feeding on small crustaceans and insect larvae. Leite (2000), showed Mylossoma spp. larvae were feeding primarily on cyclopoid copepods and insect larvae in Solimões/Amazonas river and floodplains. Rotifers were important for three species in the first exogenous feeding but, in subsequent phases, one species changed its diet to fish-larvae, $B$. cephalus, another changed to detritus, $S$. insignis and T. elongatus fed primarily on cladocerans.

Our study comprises three species belonging to the one family, which is small, compared to the size of the fish fauna in Central Amazonia. If the results of the diet of larvae were not similar for those three species, a more complex feeding behavior is expected for the larvae of other species in Solimões/Amazonas river and floodplains as well.

\section{Food size}

Fish larvae are predators and select their prey primarily by their ability of catching and ingesting them (Lazzaro, 1987, Mergulies, 1989). These two characteristics may cause similarities in the diet. Despite mouth width, all species fed on small prey, in the begining of the exogenous feeding. However, there was a relation between larvae and mouth width in a later feeding phase, where $B$. cephalus, with large mouth, fed on fish larvae, and the other two species, with small mouths, remained feeding on small 
particles. But, without exception, all species fed on larger particles as they grew. This was possible, partly, because mouth width increased more than food size, in proportion to larvae length.

Mouth diameter increase, influenced the ingestion of more robust prey in the intermediary exogenous feeding phase in the larvae. An important aspect, in this phase, in $T$. elongatus and B. cephalus larvae, was longer and not wider prey ingestion, denoting an increment on the ability of the larvae to deal with their prey.

The behavior of long and thin food ingestion, is not well documented, but it is not exclusive to juveniles from neotropical fish species. Most fish larvae studied by Merigoux \& Ponton (1998), increased the insect larvae consumption as they grew. The same behavior was observed in one of the species studied by Cervellini et al. (1993).

Comparisons of the mouth opening between species, might explain the behavior of $B$. cephalus with mouth width correspondent to $20 \%$ S.L., relative to $S$. insignis and $T$. elongatus, both with a mouth width equivalent to $5 \%$ S.L.. Fish larvae consumption by fish larva is rare, and it is usually linked to large mouthed larvae, such as Scomber scombrus (Hillgruber et al., 1997) and Scomberomorus niphonicus (Shoji et al., 1997). However, large mouth is not synonymous to a behavior of feeding on other fish larvae. Plagioscion squamosissimus larvae from the Solimões/Amazonas river, with mouth width equivalent to $20 \%$
S. L., were also feeding on copepods and insect larvae (Leite, 2000).

The use of medium sized prey items in relation to the ingestion capacity was observed here in these species. According to Dabrowski \& Bardega (1984), the fish larvae evaluated by them, in controlled conditions, selected larger prey when they were offered in high density, whereas in the lake, the same species fed on prey with diameter correspondent to the maximum of $26 \%$ of the mouth diameter. It is possible that fish larvae consume more small prey under natural conditions, where prey selection is limited.

Larvae from the three species evaluated here, replaced intermediary diameter prey by longer prey. In these cases, the prey diameter is not a good indicator of fish larvae food size. It was observed that larger diameter does not represent larger prey. Diameter gives us information about alimentary ingestion capacity yet it, does not necessarily reflect the length of the prey used as food.

In summary, aquatic plants from the flooded areas in the Solimões/ Amazonas river, are not an exclusive feeding site for $B$. cephalus, $S$. insignis and $T$. elongatus, but are a very important habitat for them. The absence of larvae with or without food in any explored habitats in river and its floodplains, depends on factors other than visibility and prey availability.

\section{Acknowledgements}

The authors thank José Vágner V. Silva for lab assistance, Dr. Richard Vogt for correction of manu- 
script and anonymous referee.

\section{Literature cited}

Almeida, R.G. 1980. Aspectos taxonômicos e hábitos alimentares de três espécies de Triportheus (Pisces:Characoidei, Characidae), do lago do Castanho, Amazonas. Dissertação de Mestrado, INPA/FUA, Manaus.

Angermeier, P.L. 1982. Resource seasonality and fish diets in an Illinois stream. Environ. Biol. of fishes 7: 251-264.

Araujo-Lima, C.A.R.M.; Portugal, L.P.S.; Ferreira, E.J.G, 1986. Fish-macrophyte relations in Anavilhanas Archipelago, a black water system in the Central Amazon. J. Fish Biol. 29: 1-2.

Araujo-Lima, C.A.R.M.; Donald, E. 1988. Número de vértebras de characiformes do rio Amazonas e seu uso na identificação de larvas do grupo. Acta Amazonica 18: 351-358.

Araujo-Lima, C.A.R.M.; Kirovsky, A.L.; Marca, A.G. 1993. As larvas dos pacus, Mylossoma spp. (Teleostei; Characidae), da Amazônia Central. Rev. Brasil. Biol. 53: 591-600.

Araujo-Lima, C.A.R.M. 1994. Egg size larval development in Central Amazonian fish. J. Fish Biology 44:371-389.

Araujo-Lima, C.A.R.M.; Goulding, M. 1997. So Fruitful a fish: ecology, conservation, and aquaculture of the Amazon's tambaqui. Columbia University Press, New York.

Bayley, P. B. 1988. Factor affecting growth rates of young tropical floodplain fishes: seasonality and density-dependence. Environ. Biol. of fishes 21: 127-142.

Boujard, T.; Sabatier, D.; Rojas-Beltran, R.; Prevost, M.F.; Reno, J.F. 1990. The food habits of three allochthonous feeding characoids in French Guiana. Rev. Ecol. (Terre Vie) 45: 247-258.

Carvalho, M.L. 1981. Alimentação do tambaqui jovem (Colossoma macropomum CUVIER, 1818) e sua relação com a comunidade zooplanctonica do Lago GrandeManaquiri, Solimões, Dissertação de
Mestrado, INPA/FUA, Manaus, Amazonas.

Cervellini, P.M.; Bsattini, M.A.; Cussac, E.E. 1993. Ontogenetic Shifts in the diet of Galaxias maculatus (Galaxidae) and Odontesthes microlepidotus (Atherinidae). Environ. Biol. of fishes 36: 283-290.

Dabrowski, K.; Bardega, R. 1984. Mouth size and predicted food size preferences of larvae of three cyprinid fish species. Aquaculture 40: 41-46.

Dumont, H.H.; Velde, I.V.; Dumont, S. 1975. The Dry Weight Estimate of Biomass in a Selection of Cladocera, Copepoda and Rotifera (Berl.). Oecologia 19: 75-97.

Fisher, T.R.; Melack, J.; Robertson, B.; Hardy, E.R.; Alves, L.F. 1983. Vertical distribution of zooplankton and physico-chemical conditions during a 24-hour period in an amazon floodplain lake - Lago Calado Brasil. Acta Amazonica 13 (3-4): 475-487.

Furch, K.; Junk, W.J. 1997. Physicochemical Conditions in Floodplains. In: Junk, W. J. (ed). The Central Amazon Floodplain - Ecology of a Pulsing System. Springer-Verlag, Berlin Heidelberg New York (pp. 109-117)

Gerking, S.D. 1994. Feeding ecology of fish. Academic Press Inc. San Diego. 415 p.

Goulding, M. 1980. The Fishes and the forest: Explorations in Amazonian Natural History. University of California Press. Berkeley, California. $280 \mathrm{pp}$.

Hardy, E.R. 1992. Changes in species composition of Cladocera and food availability in a floodplain lake, Lago Jacaretinga, Central Amazon. Amazoniana, XII :155-168.

Hillgruber, N.; Kloppmann, M.; Wahl, E.; von Westernhagen, H. 1997. Feeding of larval blue whiting and Atlantic mackerel; a comparison of foraging strategies. J. Fish Biol. 51: 230-249.

Hyatt, K.D. 1979. Feeding strategy. In: W. S. Hoar, D. J. Randall and J. R. Brett (eds.) Fish Physiology, Vol. VIII. Academic Press, London, pp. 71-119.

Ito, T.; Suzuki, R. 1977. Feeding habits of a cyprinid loach in the early stages. Bull. Freshwater Res, Lab. 27: 85-94.

Junk, W.J. 1973. Investigations on the ecology 
and production-biology of the "floatingmeadows" (Paspalo-Echinochloetum on the Midle Amazon). II - The aquatic fauna in the root-zone of floating vegetation. Amazoniana IV: 9 -102.

Korinck, V. 1984. Cladocera. In: Symoens, J.J (ed.). Hydrobiological survey of the Lake Bangweulu Luapula river basin. Belgian Ministry of National Education and French Culture. Bruxelles, 117pp.

Koste, W. 1978. Rotatoria. Dic Radertiere Mitteleuropas. Ein Bestimmungswerk, begründet von Max Voigt Überordnung Monogononta. Gebründer Borntraeger Berlin Stuttgart. 234 tab.

Lazaro, X. 1987. Foedings behaviours and seletivities, ingestion and filtcring rates of planktivorous fishes. Sciences de L'eau, 6: 11-29.

Leite, R.G. 2000. Alimentação e Fontes Autotróficas de Energia das Larvas de Peixes no rio Solimòes/Amazonas e suas Areas Inundáveis. Tese de Doutorado INPA/UA, Manaus, 118pp.

Leite, R.G.; Araujo-Lima, C.A.R.M. 2000. A dieta das larvas de Mylossoma aureum e M. duriventre na Amazônia Central. Acta Amazonica 30(1):129-147.

Lowe-McConnell, R.H. 1987. Ecological Studies in Tropical Fish Communities. Cambridge, London. 382pp.

Machado-Allison, A.J. 1987. Los peces de los llanos de Venezuela. Un ensayo sobre su Historia Natural. Univ. Central de Venezuela. Consejo de Desarrollo Científico y Humanístico. Caracas. 144pp.

McCafferty, W.P.; Provonsha, A.V. 1983. Aquatic Entomology. The Fishermen's and Ecologist illustrated Guide to Insects and their relatives. Jones \& Batlett Publishers, Inc. Boston. Portola Valley. 449pp.

Mergulies, D. 1989. Size-specific Vulnerability to Predation and Sensory system Development of White Seabass, Atractoscion nobilis, Larvac. Fish Bull. 87: 537-552.

Mćrigoux, S.; Ponton, D. 1998. Body shape, diet and ontogenetic dict shifts in young fish of the Sinnamary River, French Guiana, South America. J. Fish Biol. 52:
556-569.

Needham, J.G.; Needham, P.R. 1978. A guide to the study of Fresh-water Biology: Holden-Day Inc., San Francisco, $131 \mathrm{pp}$.

Oliveira, E.C.; Araujo-Lima, C.A.R.M. 1998. Distribuição espacial e temporal das larvas de Mylossoma duriventre c $M$. aureum no rio Amazonas. Rev. Brasil. Biol. 58: 280-29I.

Paggi, J.C. 1995. Crustacea Cladocera. In: Lopretto C. (ed.) Ecosistemas de Aguas Continentales. Metodologias para su estudio. Ediciones Sur, La Plata. p. 909-951.

Petry, P. 1989. Deriva de Ictioplancton no Paraná do Rei, várzea do Careiro. Amazônia Central, Brasil. Dissertaçào de Mestrado, INPA/FUA, Manaus. 68pp.

Rabelo, H. 1999. A dieta e o consumo diário de alimento de Cichla monoculus na Amazônia Central. Dissertação de Mestrado, INPA/FUA. Manaus. 40pp.

Robertson, B.; Hardy, E.R. 1984. Zooplankton of Amazonian Lakes and rivers. In: Sioli (ed.) The Amazon - Limnology and landscape ecology of a mighty tropical river and its basin. Monographiae Biologicae.Junk, Dordrecht, p. 337-352.

Santos, G.M. 1982. Caracterização, hábitos alimentares e reprodutivos de quatro cspécies de "aracus" e considerações ecológicas sobre o grupo no lago Janauacá-AM. (Osteichthyes, Characoidei, Anostomidae). Acta Amazonica 12(4): 713-739.

Shirota, A. 1970. Studies on the mouth size of fish larvae. Bull. Jpn. Soc. Sci. Fish 36: 353-368.

Shoji, J.; Kishida, T,; Tanaka, M. 1997. Piscivorous habits of Spanish mackerel larvae in the Seto Inland Sea. Fish. Science, 63: $388-392$.

Suárez-Mera, P.A. 1980. Allas das algaes do reservatório da Hidrelétrica de CuruáUna - Santarim (PA). CNPq. Conselho Nacional de Desenvolvimento Cientifico e Tecnológico. INPA. Instituto Nacional de Pesquisas da Amazónia. 79pp.

Aceito para publicação em 24/07/2002. 